\title{
ABCB1 (MDR1) induction defines a common resistance mechanism in paclitaxel- and olaparib-resistant ovarian cancer cells
}

\author{
Aparajitha Vaidyanathan ${ }^{1}$, Lynne Sawers ${ }^{1}$, Anne-Louise Gannon ${ }^{1}$, Probir Chakravarty ${ }^{2}$, Alison L Scott ${ }^{1}$, \\ Susan E Bray ${ }^{3}$, Michelle J Ferguson ${ }^{4}$ and Gillian Smith ${ }^{*, 1}$ \\ ${ }^{1}$ Division of Cancer Research, University of Dundee, Ninewells Hospital and Medical School, Dundee DD1 9SY, UK; \\ ${ }^{2}$ Bioinformatics and Biostatistics Service, Cancer Research UK, 44 Lincolns Inn Fields, London WC2A 3PX, UK; ${ }^{3}$ Tayside Tissue \\ Bank, University of Dundee, Ninewells Hospital and Medical School, Dundee DD1 9SY, UK and ${ }^{4}$ NHS Tayside, Ninewells Hospital \\ and Medical School, Dundee DD1 9SY, UK
}

Background: Clinical response to chemotherapy for ovarian cancer is frequently compromised by the development of drugresistant disease. The underlying molecular mechanisms and implications for prescription of routinely prescribed chemotherapy drugs are poorly understood.

Methods: We created novel A2780-derived ovarian cancer cell lines resistant to paclitaxel and olaparib following continuous incremental drug selection. MTT assays were used to assess chemosensitivity to paclitaxel and olaparib in drug-sensitive and drug-resistant cells \pm the $A B C B 1$ inhibitors verapamil and elacridar and cross-resistance to cisplatin, carboplatin, doxorubicin, rucaparib, veliparib and AZD2461. ABCB1 expression was assessed by qRT-PCR, copy number, western blotting and immunohistochemical analysis and ABCB1 activity assessed by the Vybrant and P-glycoprotein-Glo assays.

Results: Paclitaxel-resistant cells were cross-resistant to olaparib, doxorubicin and rucaparib but not to veliparib or AZD2461. Resistance correlated with increased $A B C B 1$ expression and was reversible following treatment with the $A B C B 1$ inhibitors verapamil and elacridar. Active efflux of paclitaxel, olaparib, doxorubicin and rucaparib was confirmed in drug-resistant cells and in $A B C B 1$-expressing bacterial membranes.

Conclusions: We describe a common ABCB1-mediated mechanism of paclitaxel and olaparib resistance in ovarian cancer cells. Optimal choice of PARP inhibitor may therefore limit the progression of drug-resistant disease, while routine prescription of firstline paclitaxel may significantly limit subsequent chemotherapy options in ovarian cancer patients.

Ovarian cancer, the most common and most lethal gynaecological malignancy, is commonly initially treated with combination chemotherapy, most frequently combining the platinum drug carboplatin with the taxane paclitaxel (SIGN, 2013). Although a minority of ovarian cancer patients are inherently drug resistant, development of chemotherapy-induced adaptive drug resistance is a common treatment-limiting complication in the majority of patients understanding the molecular events that lead to the development of drug-resistant disease is therefore a clinical priority (Vaughan et al,
2011). Increased understanding of causal molecular mechanisms may facilitate biomarker development to predict and monitor the onset of drug-resistant disease in individual patients and inform the most rational prescription of alternative second-line chemotherapy, where a variety of drugs are currently being evaluated in clinical trials, including the PARP inhibitors (PARPis) olaparib, veliparib (ABT888) and rucaparib (Sonnenblick et al, 2015).

PARPis are drugs that primarily inhibit PARP1 (poly (ADPribose) polymerase), an enzyme with a key role in single-strand

*Correspondence: Dr G Smith; E-mail: g.smith@dundee.ac.uk

Revised 26 May 2016; accepted 2 June 2016; published online 14 July 2016

(c) 2016 Cancer Research UK. All rights reserved 0007 - 0920/16 
break DNA repair, and were rationally designed to promote selective toxicity through exploitation of synthetic lethality resulting from targeting alternative or compensatory DNA repair pathways (Bryant et al, 2005; Farmer et al, 2005). Individuals inheriting relatively rare mutations $(5-10 \%$ of breast and ovarian cancer patients) in the tumour-suppressor genes BRCA1 or $B R C A 2$, proteins which have an essential role in homologous recombination (HR)-mediated repair of DNA double-strand breaks, have increased risk of developing breast and ovarian cancer but are particularly sensitive to olaparib and similar PARPi drugs (Audeh et al, 2010; Tutt et al, 2010). Olaparib has recently been licensed for maintenance treatment of ovarian cancer patients following first-line chemotherapy (Oza et al, 2015), while increased understanding of the molecular basis of the 'BRCA-like' or 'BRCAness' phenotype may lead to future extension of current PARPi licensing (Rouleau et al, 2010). Before PARPis can be routinely prescribed, however, it is clearly important that PARPi-induced resistance mechanisms are better understood and that the potential for treatment-limiting resistance mechanisms common both to PARPis and conventional chemotherapy is evaluated.

The majority of recent studies on PARPi-induced drug resistance mechanisms have focused on adaptive changes in the DNA damage response, for example, describing restoration of HR function following the acquisition of secondary BRCA mutations (Edwards et al, 2008; Sakai et al, 2008), HSP-90 mediated stabilisation of mutant BRCA1 (Johnson et al, 2013), RAD51 upregulation (Martin et al, 2007), loss of REV7 (Xu et al, 2015) or promotion of alternative error-prone non-homologous end joining (NHEJ) DNA repair (Patel et al, 2011). Similarity in patient chemosensitivity profiles following treatment with platinum drugs and PARPis and common resistance mechanisms where in vitro selection in one drug promotes cross-resistance to the other have been described (Edwards et al, 2008; Sakai et al, 2008; Tutt et al, 2010), while BRCA1 revertant mutations have been reported in carboplatin-resistant ovarian cancer patients (Swisher et al, 2008; Norquist et al, 2011).

In contrast, increased expression of the ATP-dependent efflux pump $A B C B 1$ (MDR1), which encodes the membrane drug transporter P-glycoprotein, is a well-described resistance mechanism for doxorubicin, paclitaxel and related taxane drugs (Shen et al, 1986; Fojo et al, 1987; Parekh et al, 1997). Increased $A B C B 1$ copy number resulting from a chromosomal amplification event at $7 \mathrm{q} 11.2-21$ has been correlated with increased $\mathrm{P}$-glycoprotein expression in paclitaxel-resistant cells from various cancers, including ovarian cancer (Wang et al, 2006), with resulting drug-resistant phenotypes confirmed in $A B C B 1$ overexpression and P-glycoprotein inhibitor studies (Lawlor et al, 2014). Intriguingly, recent reports have described increased expression of the homologous murine $A b c b 1 a$ and $A b c b 1 b$ genes in an olaparib-resistant mouse breast cancer model (Rottenberg et al, 2008) and in mouse and human lymphocytes (Dumitriu et al, 2004). A functional role for murine ATP transporters in oral bioavailability and brain accumulation of rucaparib has recently been described (Durmus et al, 2015), although the role of $A B C B 1$ in olaparib resistance in ovarian cancer has not been investigated.

We now describe the creation of a novel olaparib-resistant A2780-derived ovarian cancer cell line (A2780olapR) and highlight an $A B C B 1$-mediated resistance mechanism common to paclitaxel, doxorubicin and rucaparib. Our findings are highly clinically relevant, as our data suggest that prescription of specific PARPi as second-line or maintenance treatment may not be appropriate in the majority of ovarian cancer patients where clinical response is compromised by paclitaxel-induced drug resistance.

\section{MATERIALS AND METHODS}

Cell lines. The ovarian cancer cell line A2780 was obtained from the European Collection of Cell Culture (ECACC, https://www.phe-culturecollections.org.uk/collections/ecacc.aspx). Olaparib-resistant (A2780olapR) and paclitaxel-resistant (A2780pacR) cells were created following continuous incremental drug selection. MTT (3-(4,5-dimethylthiazol-2-yl)-2,5-diphenyltetrazolium bromide) cytotoxicity assays (Mosmann, 1983) were used as described below to assess olaparib and paclitaxel sensitivity in A2780 cells and to identify initial drug concentrations toxic to approximately $50 \%$ of cells $(1 \mu \mathrm{M}$ olaparib and $3 \mathrm{~nm}$ paclitaxel, respectively). Drug concentrations were then incrementally increased to final concentrations of $20 \mu \mathrm{M}$ (A2780olapR) to mimic typical steady-state plasma concentrations in ovarian cancer patients receiving $400 \mathrm{mg}$ olaparib daily by oral administration (Dean et al, 2012) and $2 \mu \mathrm{M}$ paclitaxel (A2780pacR), the concentration at which A2780 cells became maximally stably resistant to paclitaxel. The additional ovarian cancer cell lines A1847 (Eva et al, 1982) and PE-01 (Langdon et al, 1988) and derivative cell lines were a generous gift from Professor Roland Wolf, Division of Cancer Research, University of Dundee. All cell lines were maintained in RPMI1640 medium containing $10 \%$ fetal bovine serum and $1 \%$ penicillin/ streptomycin ( \pm selection drugs), with additional supplementation of $1 \%$ sodium pyruvate and $1 \%$ L-glutamine for PE-01 lines, in $37^{\circ} \mathrm{C}$ incubators, supplemented with $5 \% \mathrm{CO}_{2}$.

siRNA-mediated $A B C B 1$ gene knockdown. A2780pacR and A2780olapR cells $\left(2.5 \times 10^{5}\right.$ cells per well $)$ were seeded in sixwell plates and incubated for $24 \mathrm{~h}$ before transient transfections using Lipofectamine RNAi MAX (Thermo Fisher Scientific, Loughborough, UK) with a final concentration of $25 \mathrm{nM} A B C B 1-$ specific siRNA (Dharmacon SMARTpool ON-TARGETplus; GE Healthcare Life Sciences, Little Chalfont, UK) or negative control (sterile water) in serum-free medium. The extent of $A B C B 1$ knockdown was assessed by quantitative real-time PCR (qRT-PCR) analysis 24, 48 and $72 \mathrm{~h}$ following transfection, as described below.

MTT chemosensitivity assays. MTT assays (Mosmann, 1983) were used to compare the chemosensitivity of A2780, A2780olapR and A2780pacR cells and the additional cell lines described above to the chemotherapy drugs cisplatin, carboplatin, paclitaxel, doxorubicin, olaparib, AZD2461, veliparib and rucaparib and the $A B C B 1$ inhibitors verapamil and elacridar. Each cell line was plated in a 96-well plate (5000 cells per well or 3000 cells per well for A1847 and PE-01 cell lines) and treated in triplicate with serial dilutions of each drug, at concentrations selected (where possible) to mimic typical peak plasma levels in ovarian cancer patients (range $0-200 \%$ (peak plasma); cisplatin $0-25 \mu \mathrm{M}$, carboplatin $0-85 \mu \mathrm{M}$, paclitaxel $0-32 \mu \mathrm{M}$, doxorubicin $0-5.5 \mu \mathrm{M}$, olaparib $0-50 \mu \mathrm{M}$, AZD2461 $0-20 \mu \mathrm{M}$, veliparib $0-20 \mu \mathrm{M}$ and rucaparib 0 $20 \mu \mathrm{M}$; Konecny et al, 2000). For $A B C B 1$ inhibitor studies, cells were initially treated with a dose range from 0 to $100 \mu \mathrm{M}$ verapamil or elacridar to identify non-toxic inhibitor concentrations for use in future combination treatment studies, then subsequently combining 5 and $10 \mu \mathrm{m}$ verapamil or elacridar with serial dilutions of paclitaxel or olaparib. Cells were drug treated for $72 \mathrm{~h}$, media were removed and $100 \mu \mathrm{l}$ of a $0.5 \mathrm{mg} \mathrm{ml}^{-1}$ MTT solution (MTT in phenol red-free DMEM) was added, and the cells were incubated at $37^{\circ} \mathrm{C}$ for $3 \mathrm{~h}$. The resulting formazan crystals were solubilised in DMSO, quantitated spectrophotometrically at $570 \mathrm{~nm}$ and the percentage of viable cells remaining following each drug treatment was calculated (assigning a value of $100 \%$ to vehicle-treated cells). $\mathrm{IC}_{50}$ values were calculated from log dose-response curves using Prism 6 software (GraphPad Software Inc., La Jolla, CA, USA). 
RNA and DNA extraction from cell lines. Cells were grown to $80 \%$ confluency in $75 \mathrm{~cm}^{2}$ flasks, harvested by trypsinisation, counted using a haemocytometer, and $1 \times 10^{7}$ cells used for RNA extraction using RNeasy Mini Kits (Qiagen, Manchester, UK), following the manufacturer's protocol for mammalian cells, with additional on-column DNAse digestion (RNAse Free DNAse Kit, Qiagen). RNA yield and integrity were assessed from absorbance readings at 260 and $280 \mathrm{~nm}$ using a Nanodrop 1000 spectrophotometer (Thermo Fisher Scientific), according to the manufacturer's guidelines. Similarly, DNA was extracted from $3 \times 10^{6}$ cells using a DNeasy Blood and Tissue Kit (Qiagen), following the manufacturer's protocol. DNA yield was assessed from absorbance readings at $260 \mathrm{~nm}$ using a Nanodrop 1000 spectrophotometer, as described above.

qRT-PCR analysis. RNA was reverse transcribed into cDNA (200ng RNA per $50 \mu \mathrm{l}$ RT reaction) using the Taqman Reverse Transcription Reagents Kits (Life Technologies, Paisley, UK), according to the manufacturer's instructions, and the expression of $A B C B 1$ (MDR1) (Taqman probe ID Hs00184500_m1), ABCC1 (MRP1) (Taqman probe ID Hs01561502_m1), PARP1 (Taqman probe ID Hs00242302_m1) and the loading control 18S ribosomal RNA (Taqman probe ID Hs99999901_s1) was assessed by qRTPCR analysis, as previously described (Smith et al, 2012), where $20 \mu \mathrm{l}$ individual reaction mixes (per well) contained $10 \mu \mathrm{l}$ Taqman Universal PCR Master Mix (Life Technologies), $1 \mu$ l gene-specific Taqman probe, $1 \mu \mathrm{l} \mathrm{cDNA}$ and $8 \mu \mathrm{l}$ sterile water. Each reaction was performed in triplicate and run on the Standard Real Time PCR program on a 7900 Taqman real-time PCR system (Life Technologies) using predefined thermal cycling conditions $\left(50^{\circ} \mathrm{C}\right.$ for $2 \mathrm{~min}, 94.5^{\circ} \mathrm{C}$ for $10 \mathrm{~min}$ and then 40 cycles of $97^{\circ} \mathrm{C}$ for 30 seconds, $59^{\circ} \mathrm{C}$ for $1 \mathrm{~min}$ ). Analysis of gene expression was performed using SDS 2.3 software (Life Technologies); optimal experimental baselines and thresholds were chosen for each gene, and gene expression in each cell line was quantitated by cycle threshold $(\mathrm{Ct})$ values. Relative expression values were determined by comparing the expression of each target gene with the invariant 'loading control' $18 S$ ribosomal $R N A$, as previously described (Smith et al, 2012). All samples were analysed in triplicate and gene expression was calculated relative to $18 \mathrm{~S}$ ribosomal RNA \pm compound error $\left((\mathrm{SD} \text { target gene })^{2}+(\mathrm{SD} 18 \mathrm{~S} \text { ribosomal RNA })^{2}\right)^{1 / 2}$, where $\mathrm{SD}=$ standard deviation of the mean of triplicate replicates.

Copy number analysis. $A B C B 1$ (MDR1) copy number was assessed in A2780, A2780pacR and A2780olapR cells using a quantitative Taqman gene copy number assay (Taqman assay ID Hs04962504_cn), where ABCB1 copy number was compared with the copy number of the endogenous control gene RNAse P (Taqman Copy Number Reference Assay) by the comparative $\mathrm{Ct}$ method, and relative quantitation values obtained using CopyCaller Software (Life Technologies). As additional controls, $A B C B 1$ and RNAse $P$ copy numbers were assessed in peripheral blood samples $(n=2)$ obtained from healthy volunteers, and copy numbers of two were confirmed.

Western blotting. Cells for protein extraction were harvested by trypsinisation as described above and protein extracts for $A B C B 1$ analysis prepared in RIPA buffer (50 mM Tris- $\mathrm{HCl} \mathrm{pH} \mathrm{8,} 150 \mathrm{~mm}$ $\mathrm{NaCl}, 2 \mathrm{~mm}$ EDTA, $0.1 \%$ SDS, $0.5 \%$ sodium deoxycholate, $50 \mathrm{~mm}$ $\mathrm{NaF}, 1 \%$ Nonidet P-40) supplemented with EDTA-free protease inhibitor (Roche, Burgess Hill, UK) and for PARP1 analysis in $2 \times$ SDS protein sample buffer (100 mm Tris- $\mathrm{HCl} \mathrm{pH} 6.8,4 \%$ SDS, 0.04\% Bromophenol blue, 20\% Glycerol, $200 \mathrm{mM} \mathrm{DTT)} \mathrm{followed}$ by sonication of samples when required. Following $30 \mathrm{~min}$ incubation on ice with vortexing at regular intervals, lysed cells were centrifuged (14000 r.p.m., $10 \mathrm{~min}, 4^{\circ} \mathrm{C}$ ) to pellet cell debris, and protein concentrations of the resulting cell supernatants were determined by the Bradford Assay $(A B C B 1)$ or DC Protein Assay
(PARP1) (Bio-Rad, Hemel Hempstead, UK), relative to a standard curve prepared from serial dilutions of bovine serum albumin (0$\left.4 \mathrm{mg} \mathrm{ml}^{-1}\right)$, with absorbance readings at 595 or $750 \mathrm{~nm}$ respectively.

$A B C B 1$ and $P A R P 1$ expression was analysed in protein extracts from each cell line by western blotting, following SDS-PAGE. Each protein sample $(15 \mu \mathrm{g})$ was diluted in equal volumes of $2 \times$ protein sample buffer (125 mm Tris- $\mathrm{HCl}(\mathrm{pH}$ 6.8), $4 \%$ SDS, $0.02 \%$ bromophenol blue, $0.2 \mathrm{M}$ DTT, $20 \%$ glycerol), denatured and separated by $12 \%$ SDS-PAGE gels in Tris-glycine buffer $(25 \mathrm{~mm}$ Tris $\mathrm{pH} 8.3,250 \mathrm{~mm}$ glycine, $0.1 \%$ SDS). Following electrophoresis, proteins were transferred to nitrocellulose membranes in Tris-glycine-methanol buffer ( $48 \mathrm{~mm}$ Tris $\mathrm{pH} 8.3,39 \mathrm{~mm}$ glycine, $0.037 \%$ SDS, 20\% methanol) and non-specific antibody binding blocked by incubation for $2 \mathrm{~h}$ in TBST $(25 \mathrm{~mm}$ Tris- $\mathrm{HCl} \mathrm{pH} 7.6$, $150 \mathrm{~mm} \mathrm{NaCl}, 0.05 \%$ Tween-20) containing 5\% milk powder. Membranes were then incubated overnight with a mouse monoclonal $A B C B 1$ primary antibody (SC-55510, Santa Cruz Biotechnology, Heidelberg, Germany, diluted 1:1000), PARP1 (no. 9542, Santa Cruz Biotechnology, diluted 1:1000) or a mouse monoclonal $\beta$-actin antibody (sc-47778, Santa Cruz Biotechnology, diluted $1: 1000$ ), washed in PBST (PBS supplemented with $0.05 \%$ Tween-20) and incubated for $1 \mathrm{~h}$ with a goat anti-mouse polyclonal secondary antibody ( $A B C B 1 ; 170-6516$, Bio-Rad, diluted $1: 1000)$ or HRP-conjugated goat anti-rabbit polyclonal secondary antibody (PARP1; 170-6515; Bio-Rad, diluted 1:3000). Immunoblots were developed using an ECL-chemiluminescence Kit (Merck Millipore, Watford, UK), according to the manufacturer's instructions.

Immunohistochemical analysis. A2780, A2780pacR or A2780olapR cells for immunohistochemical analysis were grown in $10 \mathrm{~cm}^{2}$ dishes, harvested by scraping, centrifuged (1000 r.p.m., $5 \mathrm{~min}, \mathrm{RT}$ ) and resuspended in $50 \mu \mathrm{l}$ Normal Pooled Plasma (CCN-10, Alpha Laboratories, Eastleigh, UK). Suspended cells were pelleted by adding $50 \mu \mathrm{l}$ Bovine Thrombin (BTUD293, Diagen Reagents Ltd., Thame, UK), and cell pellets immersed in $10 \%$ neutral buffered formalin prior to overnight processing on a Leica Peloris II processor using an 8-h xylene standard protocol. Processed cells were then embedded into paraffin wax. Sections $(4 \mu \mathrm{M})$ were cut onto Superfrost plus slides (Thermo Scientific)) and dried for $1 \mathrm{~h}$ at $60^{\circ} \mathrm{C}$. Antigen retrieval and de-paraffinisation was performed using DAKO EnVision FLEX Target Retreval solution (high $\mathrm{pH}$ ) buffer in a DAKO PT Link (Dako, Ely, UK). Immunostaining using DAKO EnVision FLEX system on a DAKO Autostainer Link48 was carried out according to the manufacturer's protocol. Sections were incubated with $1 / 2000$ dilution of $A B C B 1$ primary antibody (SC-55510, Santa Cruz Biotechnology) for $30 \mathrm{~min}$. DAKO substrate working solution was used as a chromogenic agent for $2 \times 5 \mathrm{~min}$, and sections were counterstained in EnVision FLEX hematoxylin. Negative controls were prepared by replacing the primary antibody with DAKO antibody diluent.

P-glycoprotein activity assays. Assessment of drug efflux activity in A2780, A2780pacR and A2780olapR cells and the influence of the ABCB1 inhibitor verapamil was performed using the Vybrant Multidrug Resistance Assay Kit (Life Technologies), which estimates drug transporter activity by quantitative assessment of intracellular calcein accumulation. Cells were treated with the nonfluorescent prodrug calceinAM, which crosses the cell membrane by passive diffusion and is cleaved in the cytoplasm by endogenous esterases, releasing fluorescent calcein. In $A B C B 1$-expressing A2780pacR and A2780olapR cells, calceinAM is effluxed prior to esterase cleavage, resulting in reduced intracellular calcein fluorescence. A2780, A2780pacR and A2780olapR cells were plated in triplicate in cell culture medium in 96 -well microplates $\left(5 \times 10^{5}\right.$ cells per well) and incubated with $0.25 \mu \mathrm{M}$ calceinAM \pm verapamil $(0-25 \mu \mathrm{M})$ for $15 \mathrm{~min}$ at $37^{\circ} \mathrm{C}$. Microplates were then centrifuged 3 times for $5 \mathrm{~min}$ at $200 \mathrm{~g}$, the cell supernatants were removed and 
the cells re-suspended in $200 \mu \mathrm{l}$ ice-cold cell medium. Intracellular calcein fluorescence was then measured using a fluorescence microplate reader, with absorption maximum $=494 \mathrm{~nm}$ and emission maximum $=517 \mathrm{~nm}$. Relative calcein $A M$ efflux in paired drug-sensitive and drug-resistant cell lines and the influence of individual $A B C B 1$ inhibitors was assessed by plotting $\log _{10}$ doseresponse curves of calcein retention (fluorescence of inhibitor treated cells/fluorescence of untreated cells).

Independent assessment of the potential of olaparib to act as either a substrate or inhibitor of P-glycoprotein was performed using the P-glycoprotein-Glo Assay System (Promega, Southampton, UK), according to the manufacturer's guidelines. The P-glycoprotein-Glo Assay System uses recombinant P-glycoprotein membranes to assess potential drug interactions based on ATP-dependent generation of a luminescent signal following activation of firefly luciferase and therefore avoids potential confounding contributions from additional drug transporters present in cell line analyses. Baseline P-glycoprotein membrane ATPase activity was first compared with the activity of membranes treated with the selective P-glycoprotein inhibitor sodium orthovanadate (final concentration $0.1 \mathrm{~mm}$ ) to quantify any minor non-P-glycoprotein-dependent ATPase activity in the recombinant membrane preparations. Membranes were then incubated with verapamil (final concentration $200 \mu \mathrm{M}$; positive control) or with various concentrations of paclitaxel (8 and $16 \mu \mathrm{M})$, olaparib $(12.5-50 \mu \mathrm{M})$, veliparib $(25$ and $50 \mu \mathrm{M})$, rucaparib $(25$ and $50 \mu \mathrm{M})$, AZD2461 (25 and $50 \mu \mathrm{M})$, and ATPase activity was assessed by quantitative assessment of luminescence (increased in the presence of P-glycoprotein substrates and decreased in the presence of inhibitors, relative to the activity of sodium orthovanadate-treated control samples).

Whole-genome microarray mRNA analysis in A2780, A2780pacR and A2780olapR cells. RNA was prepared from A2780, A2780pacR and A2780olapR cells and integrity was assessed as described above. Each RNA sample was converted to biotinylated amplified cRNA using an Illumina TotalPrep RNA Amplification Kit (Life Technologies) according to the manufacturer's guidelines, and cRNA quality and concentration were confirmed on an Agilent Bioanalyzer 2100 (Agilent Technologies, Wokingham, UK). cRNA samples were hybridised in triplicate on Illumina Human HT-12 BeadChip Arrays (Illumina, Little Chesterford, UK) using standard protocols optimised by the Genetics Core, Wellcome Trust Clinical Research Facility, University of Edinburgh.

Bioinformatics analysis. Gene expression data were analysed using Bioconductor 2.7 (http://bioconductor.org), running on $\mathrm{R}$ 2.12.1. Normalised probe set expression measures were calculated using $\log 2$ transformation and quantile normalisation using the 'Lumi' package. To identify significant differences in gene expression in A2780, A2780pacR and A2780olapR cells, moderated Student's $t$-tests were performed using empirical Bayes statistics in the 'Limma' package, and the resulting $P$-values were adjusted for multiple testing using the false discovery rate (FDR) Benjamini and Hochberg method (Smyth, 2004); probe sets with adjusted $P$-value FDR $q<0.05$ were called differentially expressed.

\section{RESULTS}

Creation of ovarian cancer cell lines resistant to paclitaxel and olaparib. To investigate common mechanisms of paclitaxel and olaparib resistance, we created A2780-derived paclitaxel-resistant (A2780pacR) and olaparib-resistant (A2780olapR) cell lines as described in Materials and Methods section, with drug concentrations selected to mimic typical treatment protocols in ovarian cancer patients. A2780pacR cells were more than 7-fold resistant to paclitaxel (7.49-fold increase in $\mathrm{IC}_{50 \text { (paclitaxel), }}(P<0.0001$; Figure $1 \mathrm{~A}$ and $\mathrm{E}$ ), while A2780olapR cells were 36 -fold resistant to olaparib $(P<0.0001$; Figure $1 \mathrm{~B}$ and $\mathrm{E}) . \mathrm{A} 2780$ pacR cells were significantly cross-resistant to olaparib (36.95-fold increase in
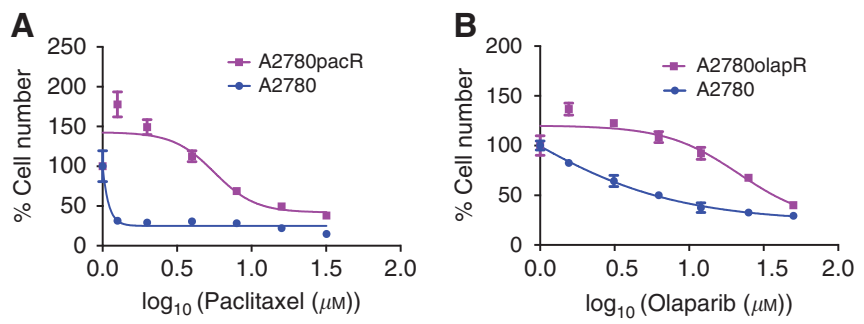

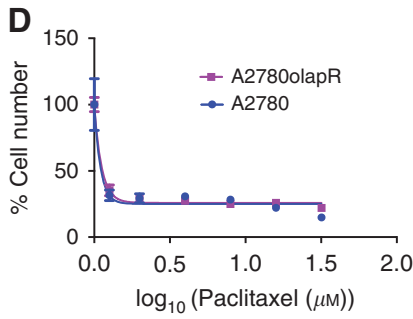

E
\begin{tabular}{|c|c|c|c|c|}
\hline & $\begin{array}{c}I_{50} \text { paclitaxel } \\
(\mu \mathrm{M})\end{array}$ & $\begin{array}{c}1 C_{50} \text { olaparib } \\
(\mu \mathrm{m})\end{array}$ & $\begin{array}{c}I_{50} \text { olaparib } \\
(\mu \mathrm{m})\end{array}$ & $\begin{array}{c}I_{50} \text { paclitaxel } \\
(\mu \mathrm{m})\end{array}$ \\
\hline A2780 & 0.75 & 0.59 & 0.59 & 0.75 \\
\hline A2780olapR & & 21.56 & & 0.58 \\
\hline A2780pacR & 5.63 & & 21.80 & \\
\hline $\begin{array}{c}\text { Fold change } \\
(P \text {-value })\end{array}$ & $\begin{array}{c}7.49 \\
(<0.0001)\end{array}$ & $\begin{array}{c}36.54 \\
(<0.0001)\end{array}$ & $\begin{array}{c}36.95 \\
(<0.0001)\end{array}$ & $(\mathrm{NS})$ \\
\hline
\end{tabular}

Figure 1. Cross-resistance of paclitaxel- and olaparib-resistant ovarian cancer cell lines. Novel ovarian cancer A2780-derived paclitaxel (A2780pacR) and olaparib (A2780olapR) resistant cell lines were created as described in Materials and Methods section. MTT chemosensitivity assays were used to compare cell viability following exposure to serial dilutions of ( $\mathbf{A}$ and $\mathbf{D})$ paclitaxel and (B and $\mathbf{C}$ ) olaparib in $\mathbf{A} 2780$ and A2780pacR (A and $\mathbf{C}$ ) and A2780olapR (B and D) cells. Chemosensitivity values obtained from triplicate replicate experiments, expressed as IC 50 values, are summarised in panel $\mathbf{E}$. 
$\mathrm{IC}_{50 \text { (olaparib), }}(P<0.0001$; Figure $1 \mathrm{C}$ and $\mathrm{E})$, although A2780olapR cells were not cross-resistant to paclitaxel (Figure 1D and E). Similarly, paclitaxel-resistant A1847TX1 and PE-01TX5 ovarian cancer cell lines were cross-resistant to olaparib (Supplementary Figure S1), supporting our hypothesis that resistance may arise by a common mechanism. Neither A2780pacR nor A2780olapR cells were cross-resistant to either cisplatin or carboplatin (data not shown).

Olaparib and paclitaxel resistance leads to increased expression of $A B C B 1$, the 'multidrug resistance' drug efflux pump. Increased $A B C B 1$ expression has previously been reported in multiple paclitaxel-resistant cell lines and has been convincingly shown to influence paclitaxel chemosensitivity. We therefore used qRT-PCR analysis to confirm lack of $A B C B 1$ mRNA expression in A2780 cells but abundant expression in both A2780pacR and A2780olapR cells (Figure 2A) and 1847TX1 and PEO1TX5 cells (Supplementary Figure S1). We then used quantitative gene copy number assays to investigate whether increased mRNA expression could be attributed to amplification of the $A B C B 1$ gene. Consistent with more abundant $A B C B 1$ mRNA expression, only A2780pacR cells were found to have amplified $A B C B 1$, with two gene copies detected in DNA extracted from whole blood samples obtained from healthy volunteers, drug-sensitive A2780 cells and A2780olapR cells but four gene copies detected in A2780pacR cells (Figure 2B). Changes in $A B C B 1$ gene expression and copy number were reflected in $A B C B 1$ protein expression, both assessed by western blotting (Figure $2 \mathrm{C}$ ) and immunohistochemical analysis (Figure 2D). Although increased P-glycoprotein expression was clearly present in both A2780pacR and A2780olapR cells, the expression was higher in A2780pacR cells, consistent with increased $A B C B 1$ copy number. As increased expression of the alternative multidrug resistance protein $A B C C 1$ ( $M R P 1$ ) has also been associated with paclitaxel resistance in various cancer cell lines (Allen et al, 2000), we additionally used qRT-PCR analysis to compare ABCC1 levels in A2780, A2780pacR and A2780olapR cells but found no differences in expression (data not shown). To extend our analysis of differential $\mathrm{ABC}$ transporter expression, we used whole-genome microarray analysis (Agilent HT-12 arrays) to perform an unbiased comparison of gene expression in A2780,
A2780pacR and A2780olapR cells, as described in Materials and Methods section. $A B C B 1$ was the only drug transporter with significantly increased expression in resistant cells (Supplementary Table S1); $A B C B 1$ probe sets were the first and second most abundantly induced probe sets from 12590 probe sets significantly altered in A2780pacR cells, and the fourth and sixth most abundantly induced probe sets from 11182 probe sets significantly altered in A2780olapR cells. It was also interesting to note that the expression of several $\mathrm{ABC}$ transporters (A2780pacR: $A B C A 1$, $A B C A 2, A B C B 7, A B C B 9, A B C C 4, A B C C 5, A B C C 6, A B C C 10$ and $A B C G 4$; A2780olapR: $A B C B 6, A B C B 9, A B C C 4, A B C D 3, A B C E 1$, $A B C F 2$ and $A B C G 4$ ) was significantly decreased in resistant cells.

Paclitaxel and olaparib resistance can be reversed by the $A B C B 1$ inhibitors verapamil and elacridar. To further test our hypothesis that resistance to both paclitaxel and olaparib is influenced by increased $A B C B 1$-mediated drug efflux, we treated A2780pacR and A2780olapR cells with the $A B C B 1$ inhibitors verapamil and elacridar. Verapamil, a calcium channel-blocker and antiarrythmic drug, is a competitive $A B C B 1$ inhibitor (Cornwell et al, 1987; Safa, 1988), while elacridar does not directly compete with $A B C B 1$ substrates for active site binding but regulates protein function through allosteric inhibition (Hyafil et al, 1993). Initial MTT assays were performed with both inhibitors in A2780, A2780pacR and A2780olapR cells to identify non-toxic doses (5 and $10 \mu \mathrm{M})$ for use in subsequent combination treatment experiments (data not shown). Dose-dependent increases in chemosensitivity were subsequently observed following combination treatment, with a complete reversal of paclitaxel resistance in both A2780pacR (Figure 3A) and A2780olapR cells (Figure 3B) treated with paclitaxel, following combination treatment with $10 \mu \mathrm{M}$ verapamil. Verapamil was a less efficient competitive inhibitor in olaparibresistant cells, although a $>80 \%$ re-sensitisation to olaparib was observed in A2780olapR cells (Figure 3C). Consistent with these findings, combination treatment with the more potent $A B C B 1$ inhibitor elacridar resulted in complete reversal of both paclitaxel and olaparib resistance (Figure 3D-F). Further, re-sensitisation to paclitaxel and olaparib was additionally observed in A2780pacR and A2780olapR cells where $A B C B 1$ expression was disrupted following transient siRNA knockdown (Supplementary Figure S2).

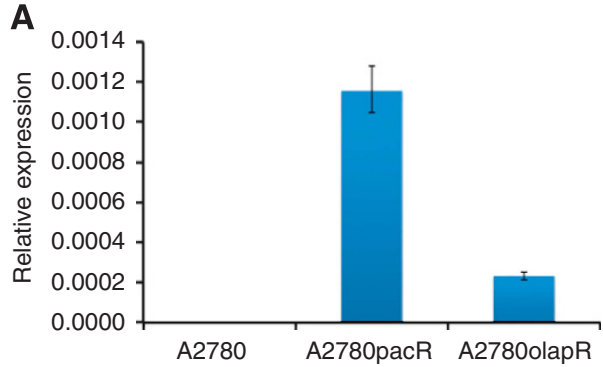

C

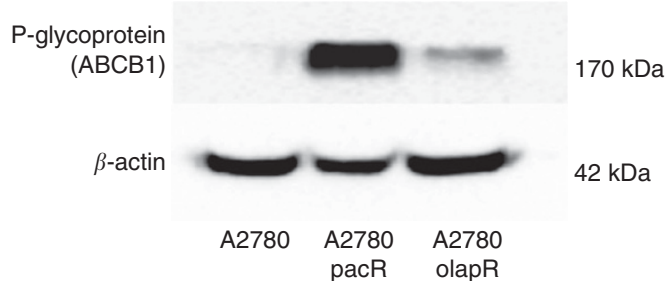

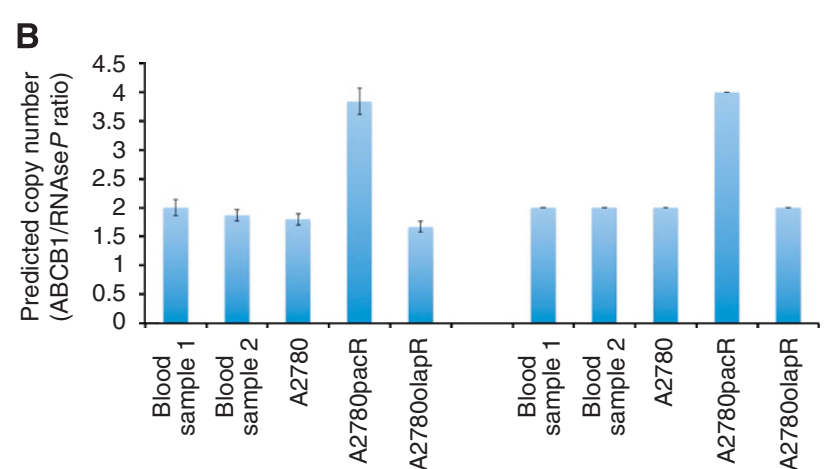

D

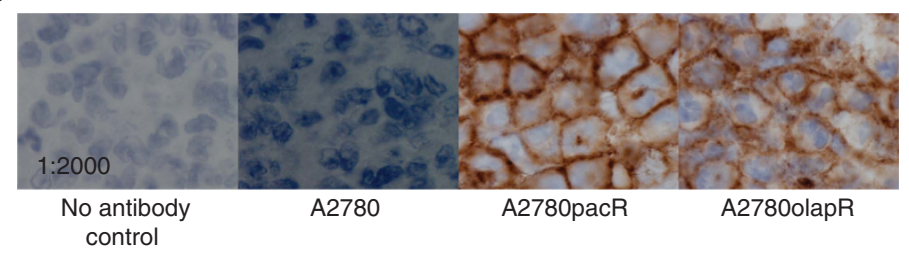

Figure 2. ABCB1 (P-glycoprotein) expression is increased in A2780pacR and A2780olapR cells. ABCB1 (A) mRNA expression, (B) copy number and (C and D) P-glycoprotein expression was compared in A2780, A2780pacR and A2780olapR cells by qRT-PCR analysis, Taqman-based copy number analysis, western blotting and immunohistochemical analysis, respectively, as described in Materials and Methods section. 

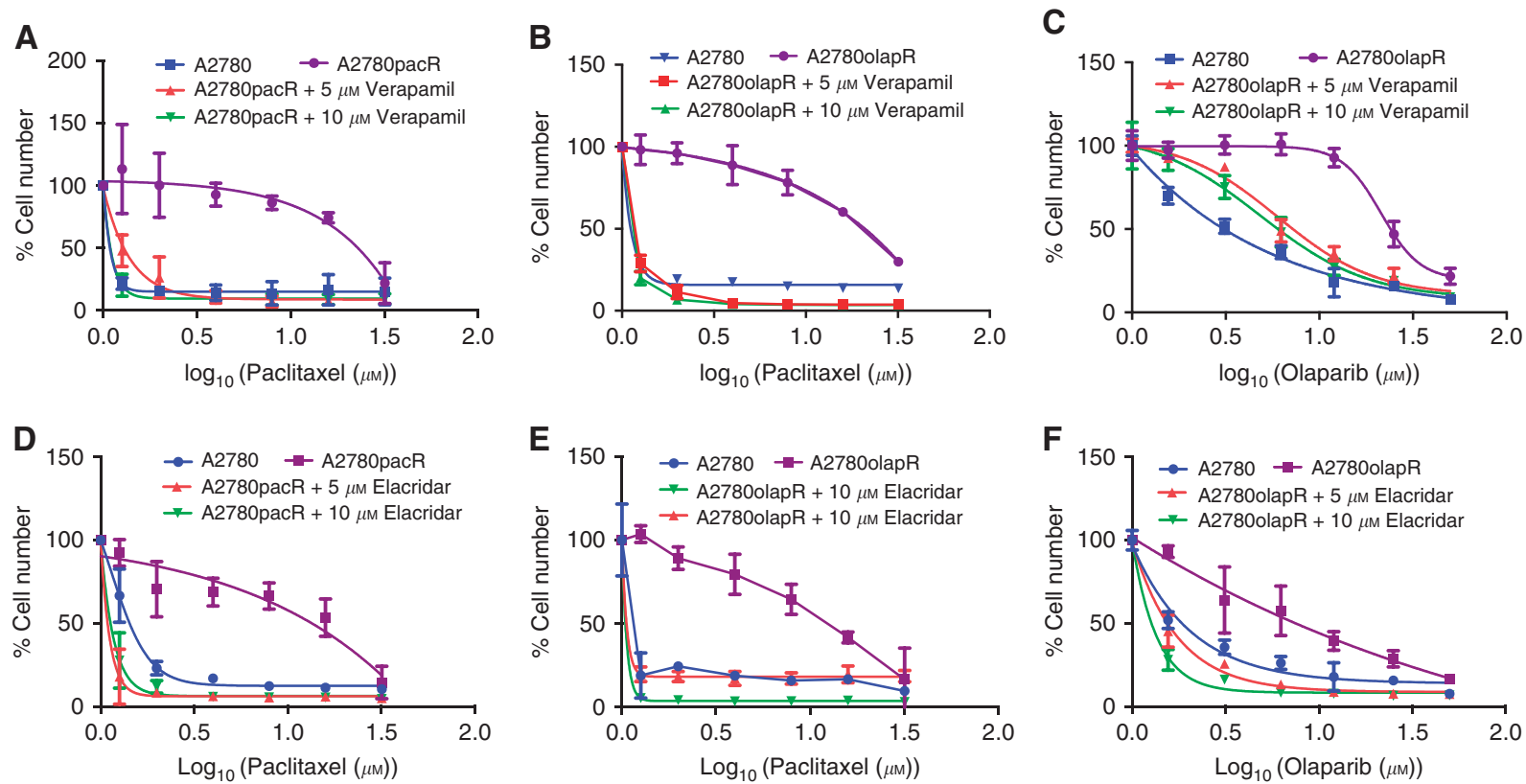

Figure 3. Paclitaxel and olaparib resistance are reversible following combination treatment with the P-glycoprotein inhibitors verapamil and elacridar. MTT chemosensitivity assays were used as described in Materials and Methods section to compare cell viability following exposure to serial dilutions of paclitaxel and olaparib in A2780, A2780pacR and A2780olapR cells in the presence and absence of combination treatments $(5 \mu \mathrm{M}$ and $10 \mu \mathrm{M})$ with the P-glycoprotein inhibitors (A-C) verapamil and (D-F) elacridar.

As $A B C B 1$ expression is approximately 10-fold higher in A2780pacR than in A2780olapR cells (panels A and B) as a consequence of a gene duplication event, it is not surprising that siRNA disruption was less effective in A2780pacR than in A2780olapR cells.

Paclitaxel and olaparib are actively effluxed from drug-resistant A2780pacR and A2780olapR cells. To investigate whether paclitaxel and olaparib are actively effluxed from drug-resistant cells, we compared the ability of A2780, A2780pacR and A2780olapR cells to efflux the model substrate CalceinAM. CalceinAM is a prodrug that is cleaved to fluorescent calcein by intracellular esterases; ATP-dependent CalceinAM efflux is increased in the presence of $A B C B 1$, thus limiting esterase cleavage and fluorescent calcein production. Consistent with increased $A B C B 1$ activity, calcein fluorescence was significantly reduced in A2780pacR and A2780olapR cells (6.18-fold $P=0.005$ and 4.49fold, $P=0.03$; Figure $4 \mathrm{~A}$ ). We then assessed intracellular calcein fluorescence in the presence of increasing concentrations of verapamil. Verapamil treatment did not influence CalceinAM efflux in drug-sensitive A2780 cells, which do not express $A B C B 1$, but caused a dose-dependent decrease in CalceinAM efflux (assessed by increased intracellular calcein fluorescence) in both A2780pacR and A2780olapR cells (Figure 4B).

To further confirm that both paclitaxel and olaparib are P-glycoprotein substrates, we used luminescent P-glycoproteinGlo assays as described in Materials and Methods section, where the influence of paclitaxel and olaparib on recombinant P-glycoprotein activity was evaluated in cell membrane fractions. Similar to verapamil (positive control), the addition of either paclitaxel or olaparib led to a dose-dependent increase in ATPase activity (indirectly assessed by relative luciferase activity), confirming a direct protein/substrate interaction (Figure 4C).

Paclitaxel- and olaparib-resistant cells are cross-resistant to doxorubicin and rucaparib but not to the alternative PARPis AZD2461 and veliparib. Liposomal doxorubicin is commonly prescribed as second-line chemotherapy to ovarian cancer patients with relapsed platinum/taxane resistant disease. The first description of $A B C B 1$-mediated drug resistance in various cancer cell lines reported both increased $A B C B 1$ mRNA expression and copy number in adriamycin (also known as doxorubicin)-resistant A2780 cells (Shen et al, 1986), while numerous subsequent studies have confirmed that doxorubicin is a P-glycoprotein substrate. We therefore predicted that paclitaxel- and olaparib-resistant cells may also be cross-resistant to doxorubicin - as expected, both A2780pacR (Figure 5A and I) and, to a lesser extent, A2780olapR (Figure 5B and I) cells were significantly more resistant to doxorubicin than A2780 cells. Similar paclitaxel/doxorubicin crossresistance was observed in A1847TX1 and PEO1TX5 cells (Supplementary Figure S1).

To investigate whether $A B C B 1$-mediated drug resistance could be avoided by prescription of an alternative PARPi, we next investigated whether A2780pacR (Figure 5C and I) or A2780olapR (Figure 5D and I) cells were cross-resistant to AZD2461, a novel PARPi with low affinity for P-glycoprotein (Jaspers et al, 2013). No cross-resistance was observed, confirming that AZD2461 is a poor P-glycoprotein substrate and suggesting that the prescription of an alternative PARPi may avoid the treatment-limiting complication of $A B C B 1$-induced drug resistance. Similarly, A2780pacR and A2780olapR cells were not cross-resistant to the PARPi veliparib (Figure 5E, $\mathrm{F}$ and I) but were significantly cross-resistant to rucaparib (Figure 5G, H and I). To further confirm that doxorubicin and rucaparib are P-glycoprotein substrates, we repeated the P-glycoprotein-Glo assays described above and demonstrated dose-dependent increases in ATPase activity following incubation with doxorubicin and rucaparib but not with any of the other PARPis tested (Figure 6). We additionally confirmed that altered chemosensitivity did not result from altered PARP1 expression in A2780pacR or A2780olapR cells, assessed both by qRT-PCR analysis and western blotting (Supplementary Figure S3) and in our whole-genome microarray analysis, described above, where we did not observe significant differences in PARP1 mRNA expression in A2780, A2780pacR and A2780olapR cells (data not shown). 
A

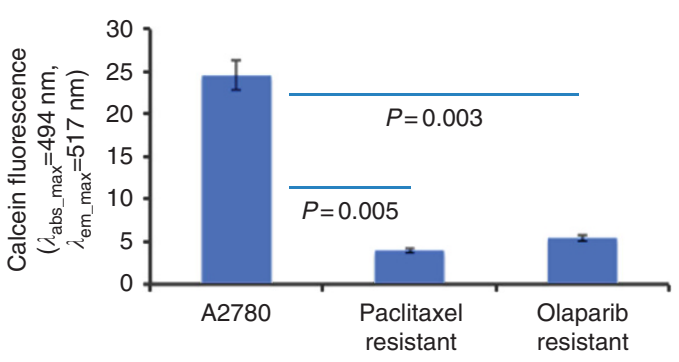

B

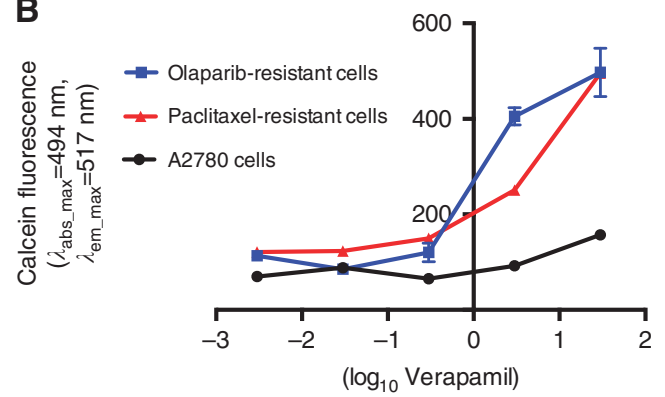

C

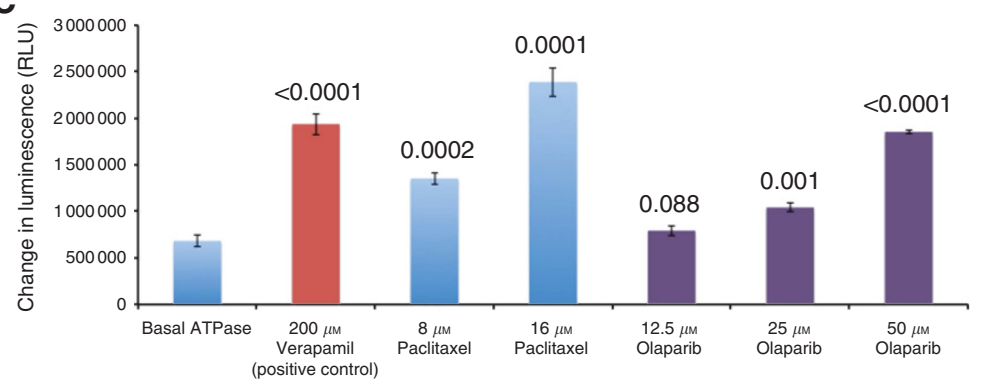

Figure 4. P-glycoprotein-mediated drug efflux is altered in paclitaxel- and olaparib-resistant cells. (A) Vybrant Multidrug Resistance Assays were used, as described in Materials and Methods section, to compare P-glycoprotein-dependent efflux of the model substrate Calcein-AM in untreated A2780, A2780pacR and A2780olapR cells and (B) in the presence of 0-25 $\mu$ M verapamil. Results were confirmed (C) using the P-glycoprotein-Glo Assay System, as described in Materials and Methods section, to demonstrate dose-dependent increases in luminescence following the incubation of paclitaxel or olaparib with P-glycoprotein-containing membranes.
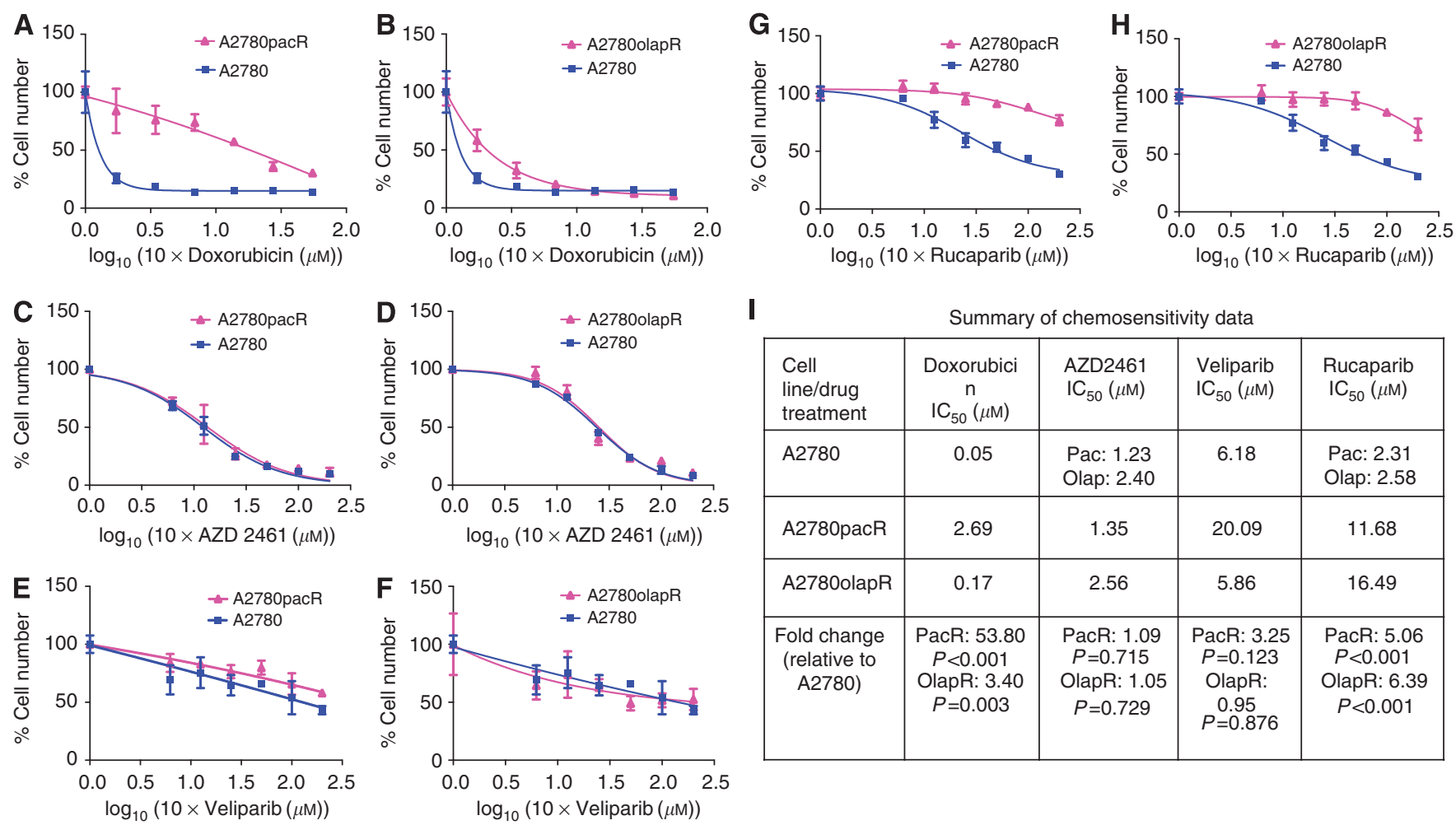

\begin{tabular}{|c|c|c|c|c|}
\hline \multicolumn{5}{|c|}{ Summary of chemosensitivity data } \\
\hline $\begin{array}{l}\text { Cell } \\
\text { line/drug } \\
\text { treatment }\end{array}$ & $\begin{array}{c}\text { Doxorubici } \\
n \\
I_{50}(\mu \mathrm{M})\end{array}$ & $\begin{array}{l}\text { AZD2461 } \\
\text { IC }_{50}(\mu \mathrm{M})\end{array}$ & $\begin{array}{l}\text { Veliparib } \\
\mathrm{IC}_{50}(\mu \mathrm{M})\end{array}$ & $\begin{array}{l}\text { Rucaparib } \\
\mathrm{IC}_{50}(\mu \mathrm{M})\end{array}$ \\
\hline A2780 & 0.05 & $\begin{array}{l}\text { Pac: } 1.23 \\
\text { Olap: } 2.40\end{array}$ & 6.18 & $\begin{array}{l}\text { Pac: } 2.31 \\
\text { Olap: } 2.58\end{array}$ \\
\hline A2780pacR & 2.69 & 1.35 & 20.09 & 11.68 \\
\hline A2780olapR & 0.17 & 2.56 & 5.86 & 16.49 \\
\hline $\begin{array}{l}\text { Fold change } \\
\text { (relative to } \\
\text { A2780) }\end{array}$ & $\begin{array}{c}\text { PacR: } 53.80 \\
P<0.001 \\
\text { OlapR: } 3.40 \\
P=0.003\end{array}$ & $\begin{array}{c}\text { PacR: } 1.09 \\
P=0.715 \\
\text { OlapR: } 1.05 \\
P=0.729\end{array}$ & $\begin{array}{c}\text { PacR: } 3.25 \\
P=0.123 \\
\text { OlapR: } \\
0.95 \\
P=0.876\end{array}$ & $\begin{array}{c}\text { PacR: } 5.06 \\
P<0.001 \\
\text { OlapR: } 6.39 \\
P<0.001\end{array}$ \\
\hline
\end{tabular}

Figure 5. Paclitaxel- and olaparib-resistant cells are cross-resistant to doxorubicin and rucaparib but not to AZD2461 or veliparib. MTT chemosensitivity assays were used as described in Materials and Methods section to compare cell viability in A2780, A2780pacR and A2780olapR cells following exposure to serial dilutions of ( $\mathbf{A}$ and $\mathbf{B}$ ) doxorubicin, (C and D) AZD2461, (E and F) veliparib and $(\mathbf{G}$ and $\mathbf{H})$ rucaparib. Chemosensitivity values obtained from triplicate replicate experiments, expressed as $I C_{50}$ values, are summarised in Panel I. 


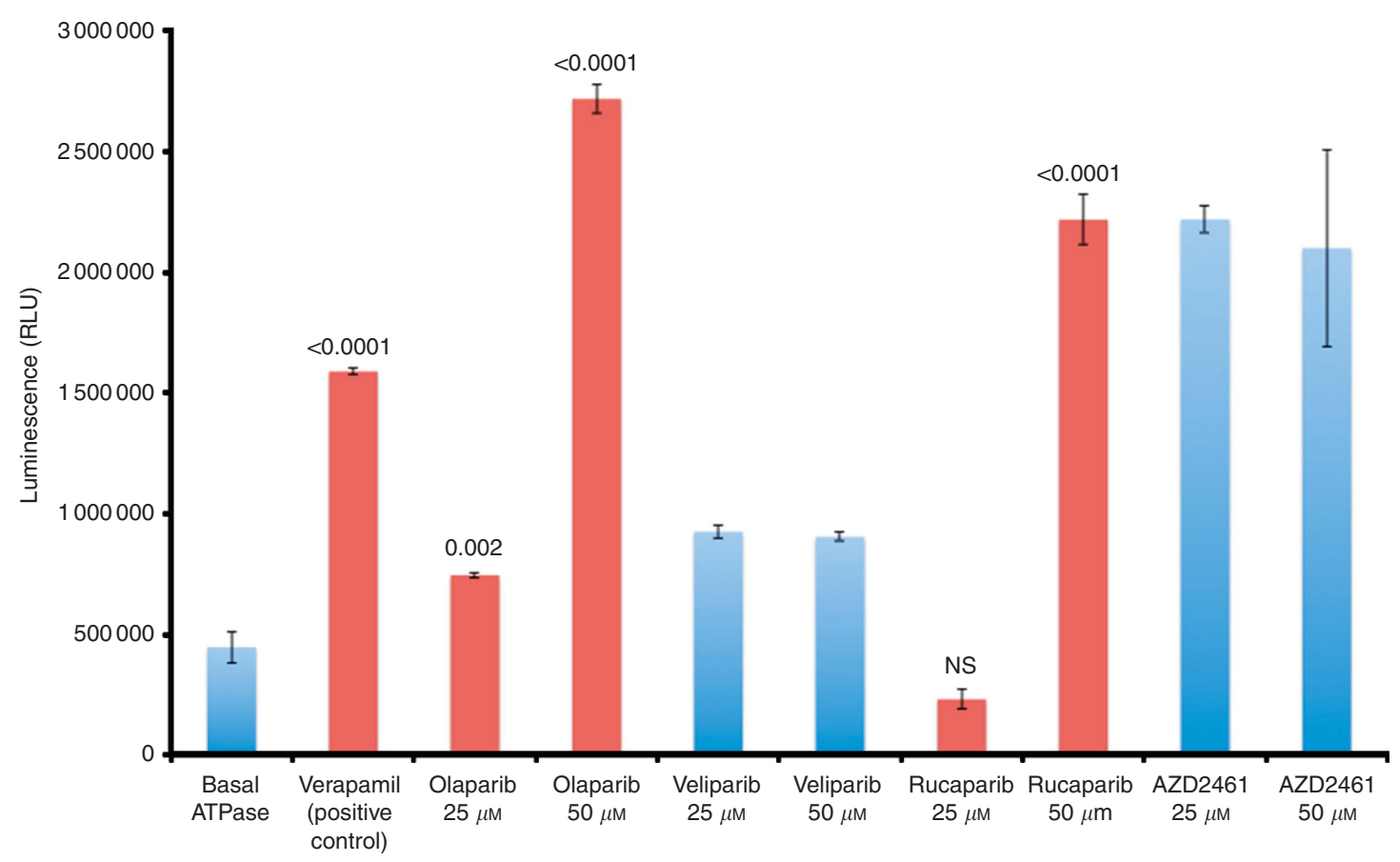

Figure 6. The PARP inhibitors olaparib and rucaparib are P-glycoprotein substrates, while the alternative PARP inhibitors AZD2461 and veliparib are not actively effluxed. The P-glycoprotein-Glo Assay System was used, as described in Materials and Methods section, to investigate whether dose-dependent increases in luminescence were observed following the incubation of verapamil (positive control), olaparib, veliparib, rucaparib or AZD2461 with P-glycoprotein-containing membranes.

\section{DISCUSSION}

The development of chemotherapy-induced drug resistance is a major treatment-limiting complication in the treatment of ovarian cancer (Vaughan et al, 2011). Many drug resistance mechanisms involve adaptation of drug metabolism or drug disposition pathways in resistant cancer cells, which normally function to protect healthy cells from exposure to toxic chemicals. One of the most well-characterised examples of cellular adaptation is increased activity of the membrane-bound ATP-dependent 'multidrug resistance' drug efflux pump P-glycoprotein, encoded by the $A B C B 1$ (MDR1) gene (Kathawala et al, 2015). Increased P-glycoprotein activity, often as a result of a chemotherapy-induced gene amplification event, has been associated with the development of drug resistance in a variety of human solid tumours and haematological cancers (Thomas and Coley, 2003). ABCB1mediated drug resistance mechanisms are of particular relevance to ovarian cancer as paclitaxel, used routinely in combination with carboplatin in first-line chemotherapy protocols, is one of the most well-characterised P-glycoprotein substrates that is efficiently effluxed from drug-resistant cells (Sikic et al, 1997).

Our data confirm many previous reports of an $A B C B 1$-mediated adaptive resistance mechanism in paclitaxel-resistant ovarian cancer cell lines and xenograft models (e.g., (Ahmed et al, 2007; Syed et al, 2011; Boesch et al, 2015; Ingemarsdotter et al, 2015) and describes a common mechanism of resistance to PARPis, including olaparib and rucaparib. $A B C B 1$-mediated resistance to PARPis is a novel finding in ovarian cancer and is of particular clinical relevance as olaparib and related drugs are currently being evaluated in multiple clinical trials as second-line or maintenance chemotherapy options, often in paclitaxel pretreated patients. It is therefore particularly important that our data suggest that some (e.g., rucaparib) but not all (e.g., veliparib, AZD2461) alternative PARPis are P-glycoprotein substrates and are actively effluxed from paclitaxel-resistant cells - optimal PARPi choice, particularly in paclitaxel-resistant patients, may therefore be an important determinant of clinical response. Consistent with this hypothesis, comparison of olaparib with the novel PARPi AZD2461 in a mouse mammary tumour model showed greater efficacy following administration of AZD2461, which we and others have shown is a poor P-glycoprotein substrate (Jaspers et al, 2013), while recent advances in PARPi development have prioritised drug candidates, for example, novel 7-azaindole-1-carboxamide derivatives, which are not P-glycoprotein substrates (Cincinelli et al, 2014). Although our A2780olapR cells were not cross-resistant to paclitaxel, we believe this to be an $A B C B 1$ threshold effect and highlight the potential for olaparib and rucaparib to additionally induce P-glycoprotein-mediated resistance, particularly if prescribed for an extended period, for example, as a long-term maintenance treatment. It is also important to note that doxorubicin, frequently prescribed to ovarian cancer patients in a liposomal formulation as second-line chemotherapy for recurrent disease, is also a wellknown P-glycoprotein substrate (Shen et al, 1986), which is also actively effluxed from paclitaxel-resistant cells.

The first suggestion that clinical response to olaparib may be compromised by altered drug efflux was proposed by Rottenberg et al (2008), describing increased murine $A b c b 1 a / b$ expression in a drug-resistant mouse mammary tumour model, where resistance was reversible with the P-glycoprotein inhibitor tariquidar (Rottenberg et al, 2008). Subsequently, increased $A b c b 1 b$ expression has been reported in a murine BRCA2-dependent breast cancer model following exposure to olaparib, docetaxel or doxorubicin (Jaspers et al, 2015), while rucaparib has recently been reported to be a substrate for both $A B C B 1$ and $A B C G 2$ (Durmus et al, 2015). Intriguingly, experiments in mouse embryonic fibroblasts have suggested that doxorubicin resistance is caused by increased P-glycoprotein expression and activity in PARP1 null cells (Wurzer et al, 2000; Wesierska-Gadek, 2005), while Dumitriu et al (2004) demonstrated that PARPis increase P-glycoprotein activity in both mouse and human lymphocytes. If a similar mechanism is present in ovarian cancer cells, sequential paclitaxel and PARPi treatment could therefore further potentiate the development of $A B C B 1$-mediated drug resistance. 
Our data suggest that both paclitaxel- and olaparib-induced resistance is reversible following combination treatment with a P-glycoprotein inhibitor. Early clinical trials of P-glycoprotein inhibitors have been disappointing, however, due in part to verapamil cardiotoxicity (Ozols et al, 1987), although a hyaluronic acid-based CD44-targeted MDR1 siRNA was recently shown to successfully reverse paclitaxel resistance in SKOV 3 cells (Yang et al, 2015) and a more recent clinical trial of tariquidar in docetaxel-treated patients demonstrated P-glycoprotein inhibition in vivo (Kelly et al, 2011). A variety of novel P-glycoprotein inhibitors are currently in development, including CB-PIC (Yun et al, 2015) and the bisbenzylisoquinoline CBT-1, a novel inhibitor that inhibits $\mathrm{P}$-glycoprotein without influencing paclitaxel pharmacokinetics (Kelly et al, 2012).

In addition to the obvious potential to target P-glycoprotein therapeutically, assessment of $A B C B 1$ copy number or P-glycoprotein $\mathrm{mRNA}$ or protein expression may also have clinical utility as drug resistance biomarkers in cancer patients. Consistent with our own data, $A B C B 1$ copy number changes or increased P-glycoprotein expression (without associated copy number changes) have been widely reported in paclitaxel and docetaxelresistant ovarian cancer cell lines (e.g., Wang et al, 2006) and in recurrent ovarian cancers (Zajchowski et al, 2012), suggesting that clinical assessment of changes in $A B C B 1$ expression or activity may have greatest prognostic potential as patients progress through chemotherapy. It is also interesting to note, however, that analysis of public domain ovarian cancer data sets from The Cancer Genome Atlas identifies a subset (approximately 2\%) of chemotherapy-naive ovarian cancer patients with $A B C B 1$ gene amplifications and a similar number of patients with high basal $A B C B 1 \mathrm{mRNA}$ expression, suggesting that these patients may be inherently resistant to paclitaxel, doxorubicin and selected PARPis. Consistent with this finding, amplification of regions of chromosome 7q21 spanning the $A B C B 1$ gene locus have frequently been described in ovarian cancer (Tapper et al, 1997; Partheen et al, 2004; Micci et al, 2014). High basal $A B C B 1$ expression has also been described in subsets of inherently resistant ovarian cancers (Holzmayer et al, 1992; Arao et al, 1994), and in a series of chemo-naive ovarian tumours where P-glycoprotein expression was inversely correlated with survival (Materna et al, 2004). Although the majority of previous studies are cell line based, it is interesting to note that $A B C B 1$ is one of the several genes with increased expression in chemo-resistant breast cancers (Krech et al, 2012) and in paclitaxel-resistant ovarian cancers (Penson et al, 2004), while a recent whole-genome sequence-based comparison of drugsensitive and drug-resistant ovarian cancers described a novel gene promoter fusion in which $A B C B 1$ is fused with $S L C 25 A 40$ in chemotherapy-resistant cancers, resulting in increased P-glycoprotein expression (Patch et al, 2015). Unfortunately, our ability to evaluate $A B C B 1$ expression in ovarian cancer patients before and following PARPi-based chemotherapy is limited by the current lack of clinical material outwith the clinical trial setting.

Should our cell line data be confirmed in vivo, we further highlight the potential for inherited differences in $A B C B 1$ activity to modify clinical response. Although not all published studies are consistent (e.g., Marsh et al, 2007; Johnatty et al, 2013), inheritance of the $A B C B 1 \mathrm{G} 2677 \mathrm{~T} / \mathrm{A}$ allele has been shown to influence paclitaxel clearance (Green et al, 2006; Fransson et al, 2011), the C2005T polymorphism to influence substrate specificity (Liu et al, 2010) and various $A B C B 1$ alleles to influence survival in both breast (Chang et al, 2009) and ovarian (Kim et al, 2009; Johnatty et al, 2013) paclitaxel-treated patient cohorts. It is therefore particularly important to note that only one-third of ovarian cancer patients responded to second-line olaparib treatment in recent clinical trials (Audeh et al, 2010), when the majority of enrolled patients had failed to respond to previous chemotherapy and almost all patients had been pretreated with paclitaxel (median of three previous chemotherapy regimens) - it is therefore tempting to speculate that non-responders had altered $A B C B 1$ expression, and we encourage testing of this hypothesis in clinical trial cohorts.

Our experimental models, combining novel drug-resistant cell lines with functional drug transport assays, provide a useful system for the evaluation of additional PARPis, and more detailed analysis of potential drug/drug interactions - studies with additional PARPis are ongoing in our laboratory. We were particularly interested to learn of a recent report describing synergistic effects of olaparib and cediranib (Liu et al, 2014), particularly as cediranib was previously shown to be a potent P-glycoprotein inhibitor (Tao et al, 2009), and hypothesised that clinical response may result from cediranib-induced inhibition of $A B C B 1$-mediated olaparib efflux. Experiments in our drug-resistant cell lines did not confirm this hypothesis (data not shown); however, consistent with a recent report suggesting that there may be an immunological basis for response to combination treatment (Lee et al, 2015).

In summary, our data describe a novel mechanism of PARPi resistance in ovarian cancer and highlights the importance of evaluating $A B C B 1$ expression in ongoing and future clinical trials. If our hypotheses are confirmed in extended clinical series, our data strongly suggest that optimal choice of PARPi may limit the progression of drug-resistant disease and further suggest that routine prescription of first-line paclitaxel may significantly limit subsequent chemotherapy options in ovarian cancer patients.

\section{ACKNOWLEDGEMENTS}

We thank the Ninewells Cancer Campaign and the Melville Robertson Trust for funding this study.

\section{CONFLICT OF INTEREST}

The authors declare no conflict of interest.

\section{REFERENCES}

Ahmed AA, Mills AD, Ibrahim AE, Temple J, Blenkiron C, Vias M, Massie CE, Iyer NG, McGeoch A, Crawford R, Nicke B, Downward J, Swanton C, Bell SD, Earl HM, Laskey RA, Caldas C, Brenton JD (2007) The extracellular matrix protein TGFBI induces microtubule stabilization and sensitizes ovarian cancers to paclitaxel. Cancer Cell 12(6): 514-527.

Allen JD, Brinkhuis RF, van Deemter L, Wijnholds J, Schinkel AH (2000) Extensive contribution of the multidrug transporters P-glycoprotein and Mrp1 to basal drug resistance. Cancer Res 60(20): 5761-5766.

Arao S, Suwa H, Mandai M, Tashiro H, Miyazaki K, Okamura H, Nomura H, Hiai H, Fukumoto M (1994) Expression of multidrug resistance gene and localization of P-glycoprotein in human primary ovarian cancer. Cancer Res 54(5): 1355-1359.

Audeh MW, Carmichael J, Penson RT, Friedlander M, Powell B, Bell-McGuinn KM, Scott C, Weitzel JN, Oaknin A, Loman N, Lu K, Schmutzler RK, Matulonis U, Wickens M, Tutt A (2010) Oral poly (ADP-ribose) polymerase inhibitor olaparib in patients with BRCA1 or BRCA2 mutations and recurrent ovarian cancer: a proof-of-concept trial. Lancet 376(9737): 245-251.

Boesch M, Zeimet AG, Rumpold H, Gastl G, Sopper S, Wolf D (2015) Drug transporter-mediated protection of cancer stem cells from ionophore antibiotics. Stem Cells Transl Med 4(9): 1028-1032.

Bryant HE, Schultz N, Thomas HD, Parker KM, Flower D, Lopez E, Kyle S, Meuth M, Curtin NJ, Helleday T (2005) Specific killing of BRCA2deficient tumours with inhibitors of poly(ADP-ribose) polymerase. Nature 434(7035): 913-917. 
Chang H, Rha SY, Jeung HC, Im CK, Ahn JB, Kwon WS, Yoo NC, Roh JK, Chung HC (2009) Association of the ABCB1 gene polymorphisms $2677 \mathrm{G}>\mathrm{T} / \mathrm{A}$ and $3435 \mathrm{C}>\mathrm{T}$ with clinical outcomes of paclitaxel monotherapy in metastatic breast cancer patients. Ann Oncol 20(2): 272-277.

Cincinelli R, Musso L, Merlini L, Giannini G, Vesci L, Milazzo FM, Carenini N, Perego P, Penco S, Artali R, Zunino F, Pisano C, Dallavalle S (2014) 7-Azaindole-1-carboxamides as a new class of PARP-1 inhibitors. Bioorg Med Chem 22(3): 1089-1103.

Cornwell MM, Pastan I, Gottesman MM (1987) Certain calcium channel blockers bind specifically to multidrug-resistant human $\mathrm{KB}$ carcinoma membrane vesicles and inhibit drug binding to P-glycoprotein. J Biol Chem 262(5): 2166-2170.

Dean E, Middleton MR, Pwint T, Swaisland H, Carmichael J, GoodegeKunwar P, Ranson M (2012) Phase I study to assess the safety and tolerability of olaparib in combination with bevacizumab in patients with advanced solid tumours. Br J Cancer 106(3): 468-474.

Dumitriu IE, Voll RE, Kolowos W, Gaipl US, Heyder P, Kalden JR, Herrmann M (2004) UV irradiation inhibits ABC transporters via generation of ADPribose by concerted action of poly(ADP-ribose) polymerase-1 and glycohydrolase. Cell Death Differ 11(3): 314-320.

Durmus S, Sparidans RW, van Esch A, Wagenaar E, Beijnen JH, Schinkel AH (2015) Breast cancer resistance protein (BCRP/ABCG2) and P-glycoprotein (P-GP/ABCB1) restrict oral availability and brain accumulation of the PARP inhibitor rucaparib (AG-014699). Pharm Res 32(1): 37-46.

Edwards SL, Brough R, Lord CJ, Natrajan R, Vatcheva R, Levine DA, Boyd J, Reis-Filho JS, Ashworth A (2008) Resistance to therapy caused by intragenic deletion in BRCA2. Nature 451(7182): 1111-1115.

Eva A, Robbins KC, Andersen PR, Srinivasan A, Tronick SR, Reddy EP, Ellmore NW, Galen AT, Lautenberger JA, Papas TS, Westin EH, WongStaal F, Gallo RC, Aaronson SA (1982) Cellular genes analogous to retroviral onc genes are transcribed in human tumour cells. Nature 295(5845): 116-119.

Farmer H, McCabe N, Lord CJ, Tutt AN, Johnson DA, Richardson TB, Santarosa M, Dillon KJ, Hickson I, Knights C, Martin NM, Jackson SP, Smith GC, Ashworth A (2005) Targeting the DNA repair defect in BRCA mutant cells as a therapeutic strategy. Nature 434(7035): 917-921.

Fojo AT, Ueda K, Slamon DJ, Poplack DG, Gottesman MM, Pastan I (1987) Expression of a multidrug-resistance gene in human tumors and tissues. Proc Natl Acad Sci USA 84(1): 265-269.

Fransson MN, Green H, Litton JE, Friberg LE (2011) Influence of Cremophor $\mathrm{EL}$ and genetic polymorphisms on the pharmacokinetics of paclitaxel and its metabolites using a mechanism-based model. Drug Metab Dispos 39(2): 247-255.

Green H, Soderkvist P, Rosenberg P, Horvath G, Peterson C (2006) mdr-1 single nucleotide polymorphisms in ovarian cancer tissue: G2677T/A correlates with response to paclitaxel chemotherapy. Clin Cancer Res 12(3 Pt 1): 854-859.

Holzmayer TA, Hilsenbeck S, Von Hoff DD, Roninson IB (1992) Clinical correlates of MDR1 (P-glycoprotein) gene expression in ovarian and small-cell lung carcinomas. J Natl Cancer Inst 84(19): 1486-1491.

Hyafil F, Vergely C, Du Vignaud P, Grand-Perret T (1993) In vitro and in vivo reversal of multidrug resistance by GF120918, an acridonecarboxamide derivative. Cancer Res 53(19): 4595-4602.

Ingemarsdotter CK, Tookman LA, Browne A, Pirlo K, Cutts R, Chelela C, Khurrum KF, Leung EY, Dowson S, Webber L, Khan I, Ennis D, Syed N, Crook TR, Brenton JD, Lockley M, McNeish IA (2015) Paclitaxel resistance increases oncolytic adenovirus efficacy via upregulated CAR expression and dysfunctional cell cycle control. Mol Oncol 9(4): 791-805.

Jaspers JE, Kersbergen A, Boon U, Sol W, van Deemter L, Zander SA, Drost R, Wientjens E, Ji J, Aly A, Doroshow JH, Cranston A, Martin NM, Lau A, O'Connor MJ, Ganesan S, Borst P, Jonkers J, Rottenberg S (2013) Loss of 53BP1 causes PARP inhibitor resistance in Brca1-mutated mouse mammary tumors. Cancer Discov 3(1): 68-81.

Jaspers JE, Sol W, Kersbergen A, Schlicker A, Guyader C, Xu G, Wessels L, Borst P, Jonkers J, Rottenberg S (2015) BRCA2-deficient sarcomatoid mammary tumors exhibit multidrug resistance. Cancer Res 75(4): 732-741.

Johnatty SE, Beesley J, Gao B, Chen X, Lu Y, Law MH, Henderson MJ, Russell AJ, Hedditch EL, Emmanuel C, Fereday S, Webb PM. Australian Ovarian Cancer Study GroupGoode EL, Vierkant RA, Fridley BL, Cunningham JM, Fasching PA, Beckmann MW, Ekici AB, Hogdall E, Kjaer SK, Jensen A, Hogdall C, Brown R, Paul J, Lambrechts S, Despierre E, Vergote I, Lester J, Karlan BY, Heitz F, du Bois A, Harter P, Schwaab I, Bean Y, Pejovic T,
Levine DA, Goodman MT, Camey ME, Thompson PJ, Lurie G, Shildkraut J, Berchuck A, Terry KL, Cramer DW, Norris MD, Haber M, MacGregor S, de Fazio A, Chenevix-Trench G (2013) ABCB1 (MDR1) polymorphisms and ovarian cancer progression and survival: a comprehensive analysis from the Ovarian Cancer Association Consortium and The Cancer Genome Atlas. Gynecol Oncol 131(1): 8-14.

Johnson N, Johnson SF, Yao W, Li YC, Choi YE, Bernhardy AJ, Wang Y, Capelletti M, Sarosiek KA, Moreau LA, Chowdhury D, Wickramanayake A, Harrell MI, Liu JF, D'Andrea AD, Miron A, Swisher EM, Shapiro GI (2013) Stabilization of mutant BRCA1 protein confers PARP inhibitor and platinum resistance. Proc Natl Acad Sci USA 110(42): 17041-17046.

Kathawala RJ, Gupta P, Ashby Jr CR, Chen ZS (2015) The modulation of ABC transporter-mediated multidrug resistance in cancer: a review of the past decade. Drug Resist Updat 18: 1-17.

Kelly RJ, Draper D, Chen CC, Robey RW, Figg WD, Piekarz RL, Chen X, Gardner ER, Balis FM, Venkatesan AM, Steinberg SM, Fojo T, Bates SE (2011) A pharmacodynamic study of docetaxel in combination with the P-glycoprotein antagonist tariquidar (XR9576) in patients with lung, ovarian, and cervical cancer. Clin Cancer Res 17(3): 569-580.

Kelly RJ, Robey RW, Chen CC, Draper D, Luchenko V, Barnett D, Oldham RK, Caluag Z, Frye AR, Steinberg SM, Fojo T, Bates SE (2012) A pharmacodynamic study of the P-glycoprotein antagonist CBT-1(R) in combination with paclitaxel in solid tumors. Oncologist 17(4): 512.

Kim HS, Kim MK, Chung HH, Kim JW, Park NH, Song YS, Kang SB (2009) Genetic polymorphisms affecting clinical outcomes in epithelial ovarian cancer patients treated with taxanes and platinum compounds: a Korean population-based study. Gynecol Oncol 113(2): 264-269.

Konecny G, Crohns C, Pegram M, Felber M, Lude S, Kurbacher C, Cree IA, Hepp H, Untch M (2000) Correlation of drug response with the ATP tumorchemosensitivity assay in primary FIGO stage III ovarian cancer. Gynecol Oncol 77(2): 258-263.

Krech T, Scheuerer E, Geffers R, Kreipe H, Lehmann U, Christgen M (2012) ABCB1/MDR1 contributes to the anticancer drug-resistant phenotype of IPH-926 human lobular breast cancer cells. Cancer Lett 315(2): 153-160.

Langdon SP, Lawrie SS, Hay FG, Hawkes MM, McDonald A, Hayward IP, Schol DJ, Hilgers J, Leonard RC, Smyth JF (1988) Characterization and properties of nine human ovarian adenocarcinoma cell lines. Cancer Res 48(21): 6166-6172.

Lawlor D, Martin P, Busschots S, Thery J, O'Leary JJ, Hennessy BT, Stordal B (2014) PARP Inhibitors as P-glyoprotein Substrates. J Pharm Sci 103(6): 1913-1920.

Lee JM, Trepel JB, Choyke P, Cao L, Sissung T, Houston N, Yu M, Figg WD, Turkbey IB, Steinberg SM, Lee MJ, Ivy SP, Liu JF, Matulonis UA, Kohn EC (2015) CECs and IL-8 have prognostic and predictive utility in patients with recurrent platinum-sensitive ovarian cancer: biomarker correlates from the randomized phase- 2 trial of olaparib and cediranib compared with olaparib in recurrent platinum-sensitive ovarian cancer. Front Oncol 5: 123.

Liu JF, Barry WT, Birrer M, Lee JM, Buckanovich RJ, Fleming GF, Rimel B, Buss MK, Nattam S, Hurteau J, Luo W, Quy P, Whalen C, Obermayer L, Lee H, Winer EP, Kohn EC, Ivy SP, Matulonis UA (2014) Combination cediranib and olaparib versus olaparib alone for women with recurrent platinum-sensitive ovarian cancer: a randomised phase 2 study. Lancet Oncol 15(11): 1207-1214.

Liu L, Fan L, Peng X, Hu D, Zhou H (2010) MDR1 C2005T polymorphism changes substrate specificity. Cancer Chemother Pharmacol 66(3): 617-623.

Marsh S, Paul J, King CR, Gifford G, McLeod HL, Brown R (2007) Pharmacogenetic assessment of toxicity and outcome after platinum plus taxane chemotherapy in ovarian cancer: the Scottish Randomised Trial in Ovarian Cancer. J Clin Oncol 25(29): 4528-4535.

Martin RW, Orelli BJ, Yamazoe M, Minn AJ, Takeda S, Bishop DK (2007) RAD51 up-regulation bypasses BRCA1 function and is a common feature of BRCA1-deficient breast tumors. Cancer Res 67(20): 9658-9665.

Materna V, Pleger J, Hoffmann U, Lage H (2004) RNA expression of MDR1/ P-glycoprotein, DNA-topoisomerase I, and MRP2 in ovarian carcinoma patients: correlation with chemotherapeutic response. Gynecol Oncol 94(1): 152-160.

Micci F, Haugom L, Abeler VM, Davidson B, Trope CG, Heim S (2014) Genomic profile of ovarian carcinomas. BMC Cancer 14: 315.

Mosmann T (1983) Rapid colorimetric assay for cellular growth and survival: application to proliferation and cytotoxicity assays. J Immunol Methods 65(1-2): 55-63.

Norquist B, Wurz KA, Pennil CC, Garcia R, Gross J, Sakai W, Karlan BY, Taniguchi T, Swisher EM (2011) Secondary somatic mutations restoring 
BRCA1/2 predict chemotherapy resistance in hereditary ovarian carcinomas. J Clin Oncol 29(22): 3008-3015.

Oza AM, Cibula D, Benzaquen AO, Poole C, Mathijssen RH, Sonke GS, Colombo N, Spacek J, Vuylsteke P, Hirte H, Mahner S, Plante M, Schmalfeldt B, Mackay H, Rowbottom J, Lowe ES, Dougherty B, Barrett JC, Friedlander M (2015) Olaparib combined with chemotherapy for recurrent platinum-sensitive ovarian cancer: a randomised phase 2 trial. Lancet Oncol 16(1): 87-97.

Ozols RF, Cunnion RE, Klecker Jr RW, Hamilton TC, Ostchega Y, Parrillo JE, Young RC (1987) Verapamil and adriamycin in the treatment of drugresistant ovarian cancer patients. J Clin Oncol 5(4): 641-647.

Parekh H, Wiesen K, Simpkins H (1997) Acquisition of taxol resistance via P-glycoprotein- and non-P-glycoprotein-mediated mechanisms in human ovarian carcinoma cells. Biochem Pharmacol 53(4): 461-470.

Partheen K, Levan K, Osterberg L, Helou K, Horvath G (2004) Analysis of cytogenetic alterations in stage III serous ovarian adenocarcinoma reveals a heterogeneous group regarding survival, surgical outcome, and substage. Genes Chromosomes Cancer 40(4): 342-348.

Patch AM, Christie EL, Etemadmoghadam D, Garsed DW, George J, Fereday S, Nones K, Cowin P, Alsop K, Bailey PJ, Kassahn KS, Newell F, Quinn MC, Kazakoff S, Quek K, Wilhelm-Benartzi C, Curry E, Leong HS. Australian Ovarian Cancer Study GroupHamilton A, Mileshkin L, Au-Yeung G, Kennedy C, Hung J, Chiew YE, Harnett P, Friedlander M, Quinn M, Pyman J, Cordner S, O'Brien P, Leditschke J, Young G, Strachan K, Waring P, Azar W, Mitchell C, Traficante N, Hendley J, Thorne H, Shackleton M, Miller DK, Arnau GM, Tothill RW, Holloway TP, Semple T, Harliwong I, Nourse C, Nourbakhsh E, Manning S, Idrisoglu S, Bruxner TJ, Christ AN, Poudel B, Holmes O, Anderson M, Leonard C, Lonie A, Hall N, Wood S, Taylor DF, Xu Q, Fink JL, Waddell N, Drapkin R, Stronach E, Gabra H, Brown R, Jewell A, Nagaraj SH, Markham E, Wilson PJ, Ellul J, McNally O, Doyle MA, Vedururu R, Stewart C, Lengyel E, Pearson JV, Waddell N, de Fazio A, Grimmond SM, Bowtell DD (2015) Whole-genome characterization of chemoresistant ovarian cancer. Nature 521(7553): 489-494.

Patel AG, Sarkaria JN, Kaufmann SH (2011) Nonhomologous end joining drives poly(ADP-ribose) polymerase (PARP) inhibitor lethality in homologous recombination-deficient cells. Proc Natl Acad Sci USA 108(8): 3406-3411.

Penson RT, Oliva E, Skates SJ, Glyptis T, Fuller Jr AF, Goodman A, Seiden MV (2004) Expression of multidrug resistance-1 protein inversely correlates with paclitaxel response and survival in ovarian cancer patients: a study in serial samples. Gynecol Oncol 93(1): 98-106.

Rottenberg S, Jaspers JE, Kersbergen A, van der Burg E, Nygren AO, Zander SA, Derksen PW, de Bruin M, Zevenhoven J, Lau A, Boulter R, Cranston A, O'Connor MJ, Martin NM, Borst P, Jonkers J (2008) High sensitivity of BRCA1-deficient mammary tumors to the PARP inhibitor AZD2281 alone and in combination with platinum drugs. Proc Natl Acad Sci USA 105(44): 17079-17084.

Rouleau M, Patel A, Hendzel MJ, Kaufmann SH, Poirier GG (2010) PARP inhibition: PARP1 and beyond. Nat Rev Cancer 10(4): 293-301.

Safa AR (1988) Photoaffinity labeling of the multidrug-resistance-related P-glycoprotein with photoactive analogs of verapamil. Proc Natl Acad Sci USA 85(19): 7187-7191.

Sakai W, Swisher EM, Karlan BY, Agarwal MK, Higgins J, Friedman C, Villegas E, Jacquemont C, Farrugia DJ, Couch FJ, Urban N, Taniguchi T (2008) Secondary mutations as a mechanism of cisplatin resistance in BRCA2-mutated cancers. Nature 451(7182): 1116-1120.

Shen DW, Fojo A, Chin JE, Roninson IB, Richert N, Pastan I, Gottesman MM (1986) Human multidrug-resistant cell lines: increased mdr1 expression can precede gene amplification. Science 232(4750): 643-645.

SIGN (2013) SIGN 135: Management of Epithelial Ovarian Cancer. A National Clinical Guideline Edinburgh, UK.

Sikic BI, Fisher GA, Lum BL, Halsey J, Beketic-Oreskovic L, Chen G (1997) Modulation and prevention of multidrug resistance by inhibitors of P-glycoprotein. Cancer Chemother Pharmacol 40: Suppl: S13-S19.

Smith G, Ng MT, Shepherd L, Herrington CS, Gourley C, Ferguson MJ, Wolf CR (2012) Individuality in FGF1 expression significantly influences platinum resistance and progression-free survival in ovarian cancer Br J Cancer 107(8):1327-1336.
Smyth GK (2004) Linear models and empirical bayes methods for assessing differential expression in microarray experiments. Stat Appl Genet Mol Biol 3: Article3.

Sonnenblick A, de Azambuja E, Azim Jr. HA, Piccart M (2015) An update on PARP inhibitors-moving to the adjuvant setting. Nat Rev Clin Oncol 12(1): 27-41.

Swisher EM, Sakai W, Karlan BY, Wurz K, Urban N, Taniguchi T (2008) Secondary BRCA1 mutations in BRCA1-mutated ovarian carcinomas with platinum resistance. Cancer Res 68(8): 2581-2586.

Syed N, Coley HM, Sehouli J, Koensgen D, Mustea A, Szlosarek P, McNeish I, Blagden SP, Schmid P, Lovell DP, Hatzimichael E, Crook T (2011) Pololike kinase Plk2 is an epigenetic determinant of chemosensitivity and clinical outcomes in ovarian cancer. Cancer Res 71(9): 3317-3327.

Tao LY, Liang YJ, Wang F, Chen LM, Yan YY, Dai CL, Fu LW (2009) Cediranib (recentin, AZD2171) reverses ABCB1- and ABCC1-mediated multidrug resistance by inhibition of their transport function. Cancer Chemother Pharmacol 64(5): 961-969.

Tapper J, Butzow R, Wahlstrom T, Seppala M, Knuutila S (1997) Evidence for divergence of DNA copy number changes in serous, mucinous and endometrioid ovarian carcinomas. Br J Cancer 75(12): 1782-1787.

Thomas H, Coley HM (2003) Overcoming multidrug resistance in cancer: an update on the clinical strategy of inhibiting p-glycoprotein. Cancer Control 10(2): 159-165.

Tutt A, Robson M, Garber JE, Domchek SM, Audeh MW, Weitzel JN, Friedlander M, Arun B, Loman N, Schmutzler RK, Wardley A, Mitchell G, Earl H, Wickens M, Carmichael J (2010) Oral poly(ADP-ribose) polymerase inhibitor olaparib in patients with BRCA1 or BRCA2 mutations and advanced breast cancer: a proof-of-concept trial. Lancet 376(9737): 235-244.

Vaughan S, Coward JI, Bast Jr RC, Berchuck A, Berek JS, Brenton JD, Coukos G, Crum CC, Drapkin R, Etemadmoghadam D, Friedlander M, Gabra H, Kaye SB, Lord CJ, Lengyel E, Levine DA, McNeish IA, Menon U, Mills GB, Nephew KP, Oza AM, Sood AK, Stronach EA, Walczak H, Bowtell DD, Balkwill FR (2011) Rethinking ovarian cancer: recommendations for improving outcomes. Nat Rev Cancer 11(10): 719-725.

Wang YC, Juric D, Francisco B, Yu RX, Duran GE, Chen GK, Chen X, Sikic BI (2006) Regional activation of chromosomal arm $7 \mathrm{q}$ with and without gene amplification in taxane-selected human ovarian cancer cell lines. Genes Chromosomes Cancer 45(4): 365-374.

Wesierska-Gadek J (2005) Major contribution of the multidrug transporter P-glycoprotein to reduced susceptibility of poly(ADP-ribose) polymerase1 knock-out cells to doxorubicin action. J Cell Biochem 95(5): 1012-1028.

Wurzer G, Herceg Z, Wesierska-Gadek J (2000) Increased resistance to anticancer therapy of mouse cells lacking the poly(ADP-ribose) polymerase attributable to up-regulation of the multidrug resistance gene product P-glycoprotein. Cancer Res 60(15): 4238-4244.

Xu G, Chapman JR, Brandsma I, Yuan J, Mistrik M, Bouwman P, Bartkova J, Gogola E, Warmerdam D, Barazas M, Jaspers JE, Watanabe K, Pieterse M, Kersbergen A, Sol W, Celie PH, Schouten PC, van den Broek B, Salman A, Nieuwland M, de Rink I, de Ronde J, Jalink K, Boulton SJ, Chen J, van Gent DC, Bartek J, Jonkers J, Borst P, Rottenberg S (2015) REV7 counteracts DNA double-strand break resection and affects PARP inhibition. Nature 521(7553): 541-544.

Yang X, Iyer AK, Singh A, Choy E, Hornicek FJ, Amiji MM, Duan Z (2015) MDR1 siRNA loaded hyaluronic acid-based CD44 targeted nanoparticle systems circumvent paclitaxel resistance in ovarian cancer. Sci Rep 5: 8509.

Yun M, Lee D, Park MN, Kim EO, Sohn EJ, Kwon BM, Kim SH (2015) Cinnamaldehyde derivative (CB-PIC) sensitizes chemo-resistant cancer cells to drug-induced apoptosis via suppression of MDR1 and its upstream STAT3 and AKT signalling. Cell Physiol Biochem 35(5): 1821-1830.

Zajchowski DA, Karlan BY, Shawver LK (2012) Treatment-related protein biomarker expression differs between primary and recurrent ovarian carcinomas. Mol Cancer Ther 11(2): 492-502.

This work is published under the standard license to publish agreement. After 12 months the work will become freely available and the license terms will switch to a Creative Commons AttributionNonCommercial-Share Alike 4.0 Unported License.

Supplementary Information accompanies this paper on British Journal of Cancer website (http://www.nature.com/bjc) 